\title{
A Phylogenetic Analysis of the Genus Saccharomonospora Conducted with 16S rRNA Gene Sequences
}

\author{
SAM-BONG KIM, ${ }^{1,2}$ JUNG-HOON YOON, ${ }^{2,3}$ HONGIK KIM, ${ }^{2}$ SUNG TAIK LEE, ${ }^{3}$ \\ YONG-HA PARK, ${ }^{2}$ AND MICHAEL GOODFELLOW ${ }^{1 *}$ \\ Department of Microbiology, The Medical School, Newcastle upon Tyne, United Kingdom, ${ }^{1}$ and Bioinformatics \\ and Systematics Laboratory, Korean Collection of Type Cultures, Genetic Engineering Research Institute, \\ Korean Institute of Science and Technology, Daeduk Science Park, ${ }^{2}$ and Department of \\ Biotechnology, Korea Advanced Institute of Science and \\ Technology, ${ }^{3}$ Taejon, Republic of Korea
}

\begin{abstract}
Nearly complete sequences of 16S rRNA genes of representative strains of the genus Saccharomonospora were determined following the isolation and cloning of the amplified genes. The sequences were aligned with those of representatives of the family Pseudonocardiaceae, and a phylogenetic tree was inferred by the neighborjoining method. The genus Saccharomonospora formed a distinct clade within the evolutionary radiation encompassed by the family Pseudonocardiaceae. The average nucleotide similarity value found between the type strains of the four validly described Saccharomonospora species was $97.5 \% \pm 1.0 \%$. The most distant relationship was found between Saccharomonospora azurea and Saccharomonospora viridis K73 (96.3\% similarity). In contrast, Saccharomonospora azurea K161 and "Saccharomonospora caesia" K163 had identical 16S rRNA gene sequences. The nucleotide sequence data suggest that the genus Saccharomonospora contains several new centers of variation.
\end{abstract}

The genus Saccharomonospora was proposed by Nonomura and Ohara (30) for monosporic actinomycetes that contained meso-diaminopimelic acid, arabinose, and galactose in the peptidoglycan (wall chemotype IV sensu Lechevalier Lechevalier [25]). Subsequently, additional chemical markers were found to characterize the taxon, notably the presence of major amounts of $i$ so- and anteiso-fatty acids, 2-hydroxy fatty acids, phosphatidylethanolamine, and menaquinones that were tetrahydrogenated with nine isoprene units $(21,25)$.

There are currently four validly described Saccharomonospora species, namely, Saccharomonospora azurea (32), Saccharomonospora cyanea (33), Saccharomonospora glauca (17), and Saccharomonospora viridis (30), the type species of the genus. A fifth species, "Saccharomonospora caesia," was proposed by Greiner-Mai et al. (18) for organisms previously classified as Micropolyspora caesia $(20,22)$; this organism did not appear in the Approved Lists of Bacterial Names (35) and has not been added subsequently, and hence, it has not been validly published. It is important to distinguish between members of validly described and putatively new Saccharomonospora species, as some kinds of saccharomonosporae can cause hypersensitivity pneumonitis. $S$. viridis is strongly implicated as one the causal agents of farmer's lung disease $(3,16)$.

It is also important to determine the taxonomic structure of the genus Saccharomonospora in order to discover the relationships between the existing taxa and between them and prospective new species. It appears from preliminary $16 \mathrm{~S}$ rRNA sequence studies that the genus Saccharomonospora forms a distinct phyletic line within the evolutionary radiation encompassed by the family Pseudonocardiaceae $(5,9,10,28$, 36). To date, three Saccharomonospora strains have been the subject of 16S rRNA sequencing analyses, the type strain of $S$. viridis, the putative type strain of " $S$. caesia," and an isolate

${ }^{*}$ Corresponding author. Mailing address: Department of Microbiology, The Medical School, Framlington Place, Newcastle upon Tyne NE2 4HH, United Kingdom. Phone: 41-91-222-7706. Fax: 41-91-2227736. from stored grain, Saccharomonospora sp. strain A1206, that was tentatively considered, subject to additional sequencing studies, to be the nucleus of a new species (36). In the present investigation, the partial sequences of the 16S rRNA genes (16S rDNA) of an additional 13 representative Saccharomonospora strains were examined.

\section{MATERIALS AND METHODS}

Selective isolation. Mushroom compost samples collected from Somerset, United Kingdom, and a hay sample from Rothamsted Experimental Station, Harpenden, United Kingdom, were dried at room temperature for 2 or 3 days. The dried hay $(5 \mathrm{~g})$ and mushroom compost samples $(2 \mathrm{~g})$ were transferred to nylon mesh bags which were inflated with compressed air prior to sealing. The preparations were vigorously shaken for $5 \mathrm{~min}$ to produce aerial spore suspensions that were thoroughly mixed for $5 \mathrm{~min}$ by the electric fan in a sedimentation chamber. The bags were left to stand for $90 \mathrm{~min}$, and the spore cloud was sampled with a six-stage viable-particle sampler (Andersen 2000 Inc., Atlanta, Ga.) (2).

The inflated bags were attached to the inlet cone of the Andersen sampler, and air containing the spores was drawn through the system for $20 \mathrm{~s}$ with a vacuum pump. The spore clouds were impacted onto open petri dishes that contained R8 agar (1), half-strength tryptic soy agar (Difco), and half-strength tryptic soy agar supplemented with adenine $(0.4 \%$, wt $/ \mathrm{vol})$ and streptomycin $(16 \mu \mathrm{g} / \mathrm{ml})$; all three media also contained cycloheximide at $50 \mu \mathrm{g} / \mathrm{ml}$. The agar plates were prepared in duplicate; one set was incubated at $30^{\circ} \mathrm{C}$ and the other was incubated at $50^{\circ} \mathrm{C}$ for 2 weeks, when the number of Saccharomonospora-like colonies was counted. Saccharomonosporae were readily recognized on isolation plates, as they produced a characteristic grayish-green aerial spore mass. The aerial hyphae were seen to carry single spores when examined with an Optiphot binocular light microscope fitted with a long distance objective (X400 magnification; Nikon Kogaru K.K., Tokyo, Japan).

Sixty-seven colonies were taken from the isolation plates with sterile toothpicks and inoculated onto R8 agar (1) plates that were incubated at either $30^{\circ} \mathrm{C}$ for 7 days or $50^{\circ} \mathrm{C}$ for 3 days (depending on the temperature at which the original isolation plates were incubated). Suspensions of spores and hyphal fragments were prepared in sterile glycerol $\left(20 \%\right.$, vol/vol; Analar; BDH) and kept at $-20^{\circ} \mathrm{C}$ (37). The tests strains were also maintained on R8 agar (1) plates.

Organisms and culture conditions. Representatives of Saccharomonospora species were examined together with five randomly chosen strains (Table 1) isolated from the hay and mushroom compost samples on R8 agar plates incubated at $50^{\circ} \mathrm{C}$. Biomass of the test strains was prepared in shake flasks of tryptic soy broth, supplemented with glucose $(0.75 \%$, wt $/ \mathrm{vol})$, at $45^{\circ} \mathrm{C}$ for $48 \mathrm{~h}$. At maximum growth, the broth cultures were checked for purity, harvested by centrifugation, and washed twice in $10 \mathrm{ml}$ of saline-EDTA $(0.15 \mathrm{M} \mathrm{NaCl}, 0.1 \mathrm{M}$ EDTA; pH 8.0). Competent cells of Escherichia coli DH5 $\alpha F^{\prime}$ (Promega Co., 
TABLE 1. Strains used in the $16 \mathrm{~S}$ rDNA sequence analyses

\begin{tabular}{|c|c|c|c|c|}
\hline Laboratory no. ${ }^{a}$ & Species & Strain designation and/or source ${ }^{b}$ & $\begin{array}{l}\text { Nucleotide sequence } \\
\text { accession no. }\end{array}$ & $\begin{array}{l}\text { Source of } \\
\text { data }^{c}\end{array}$ \\
\hline $\mathrm{K} 209^{\mathrm{T}}$ & Actinokineospora riparia & IFO $14541^{\mathrm{T}}$ & $\mathrm{X} 76953$ & RDP \\
\hline $\mathrm{K} 210^{\mathrm{T}}$ & Amycolatopsis azurea & NRRL $11412^{\mathrm{T}}$ & X53199 & RDP \\
\hline $\mathrm{K} 156^{\mathrm{T}}$ & Amycolatopsis fastidiosa & ATCC $31181^{\mathrm{T}}$ & X53200 & RDP \\
\hline $\mathrm{K} 98^{\mathrm{T}}$ & Amycolatopsis mediterranei & ATCC $13685^{\mathrm{T}}$ & $\mathrm{X} 76957$ & RDP \\
\hline $239^{\mathrm{T}}$ & Amycolatopsis methanolica & NRRL $11412^{\mathrm{T}}$ & X54274 & RDP \\
\hline $\mathbf{K} 99^{\mathrm{T}}$ & Amycolatopsis orientalis & ATCC $19795^{\mathrm{T}}$ & X76958 & RDP \\
\hline K159 & Kibdelosporangium aridum & ATCC $39323^{\mathrm{T}}$ & X53191 & RDP \\
\hline NA & Mycobacterium bovis & Strain BCG & M20940 & RDP \\
\hline $\mathrm{K} 211^{\mathrm{T}}$ & Pseudonocardia alni & V. N. Akimov; VKM AC901 ${ }^{\mathrm{T}}$ & X76954 & RDP \\
\hline $\mathrm{K} 402^{\mathrm{T}}$ & Pseudonocardia autotrophica & ATCC $19727^{\mathrm{T}}$ & X54288 & RDP \\
\hline $\mathrm{P} 435^{\mathrm{T}}$ & Pseudonocardia compacta & DSM $43592^{\mathrm{T}}$ & X55609 & RDP \\
\hline $\mathrm{K} 141^{\mathrm{T}}$ & Pseudonocardia halophobica & DSM $43089^{\mathrm{T}}$ & Z14111 & RDP \\
\hline $\mathrm{K} 428^{\mathrm{T}}$ & Pseudonocardia hydrocarbonoxydans & DSM $43281^{\mathrm{T}}$ & $\mathrm{X} 76955$ & RDP \\
\hline $\mathrm{K} 212^{\mathrm{T}}$ & Pseudonocardia nitrificans & DSM $46012^{\mathrm{T}}$ & X55609 & RDP \\
\hline $\mathrm{K} 213^{\mathrm{T}}$ & Pseudonocardia petroleophila & DSM $43193^{\mathrm{T}}$ & X55608 & RDP \\
\hline $\mathrm{A} 195^{\mathrm{T}}$ & Pseudonocardia saturnea & DSM $43195^{\mathrm{T}}$ & X76956 & RDP \\
\hline $\mathrm{K} 160^{\mathrm{T}}$ & Pseudonocardia thermophila & DSM $19285^{\mathrm{T}}$ & X53195 & RDP \\
\hline $\mathrm{K} 161^{\mathrm{T}}$ & Saccharomonospora azurea & H. Runmao; NA128 & Z38017 & This study \\
\hline $\mathrm{K} 76^{\mathrm{T}}$ & "Saccharomonospora caesia" & INMI $19125^{\mathrm{T}}$ & $\mathrm{X} 76960$ & RDP \\
\hline K163 & "Saccharomonospora caesia" & DSM 43068 & Z38019 & This study \\
\hline $\mathrm{K} 168^{\mathrm{T}}$ & Saccharomonospora cyanea & H. Runmao; NA134 ${ }^{\mathrm{T}}$ & $\mathrm{Z} 38018$ & This study \\
\hline $\mathrm{K} 169^{\mathrm{T}}$ & Saccharomonospora glauca & DSM $43769^{\mathrm{T}}$ & $\mathrm{Z} 38003$ & This study \\
\hline $\mathrm{K} 202$ & Saccharomonospora sp. & J.-S. Ruan; 350; soil & $\mathrm{Z} 38004$ & This study \\
\hline $\mathrm{K} 73^{\mathrm{T}}$ & Saccharomonospora viridis & NCIB $9602^{\mathrm{T}}$ & Z38007 & This study \\
\hline K191 & Saccharomonospora viridis & E. Greiner-Mai; R25 & $\mathrm{Z} 38021$ & This study \\
\hline K180 & Saccharomonospora sp. & A. J. McCarthy; municipal refuge compost, Germany & $\mathrm{Z} 38020$ & This study \\
\hline SB-01 & Saccharomonospora sp. & S.-B. Kim; mushroom compost, phase I & $\mathrm{Z} 38022$ & This study \\
\hline SB-22 & Saccharomonospora sp. & S.-B. Kim; cooked-out mushroom compost & $\mathrm{Z} 38023$ & This study \\
\hline SB-33 & Saccharomonospora sp. & S.-B. Kim; hay ${ }^{d}$ & $\mathrm{Z} 38005$ & This study \\
\hline SB-37 & Saccharomonospora sp. & S.-B. Kim; hay ${ }^{d}$ & $\mathrm{Z} 38006$ & This study \\
\hline SB-58 & Saccharomonospora sp. & S.-B. Kim; mushroom compost, end of phase II & $\mathrm{Z} 38024$ & This study \\
\hline NA & Saccharomonospora sp. & J. Lacey; A1206 & X76961 & RDP \\
\hline $\mathrm{D} 432$ & Saccharopolyspora erythraea & NRRL 2338 & X53198 & RDP \\
\hline $\mathrm{A} 85^{\mathrm{T}}$ & Saccharopolyspora gregorii & NCIB $12823^{\mathrm{T}}$ & $\times 76962$ & RDP \\
\hline $\mathrm{K} 16^{\mathrm{T}}$ & Saccharopolyspora hirsuta & ATCC $27875^{\mathrm{T}}$ & X53196 & RDP \\
\hline A $54^{\mathrm{T}}$ & Saccharopolyspora hordei & NCIB $12824^{\mathrm{T}}$ & X53197 & RDP \\
\hline $\mathrm{F} 1^{\mathrm{T}}$ & Saccharopolyspora rectivirgula & ATCC $33515^{\mathrm{T}}$ & X53194 & RDP \\
\hline $\mathrm{K} 204^{\mathrm{T}}$ & Saccharothrix autraliensis & ATCC $31947^{\mathrm{T}}$ & X54193 & RDP \\
\hline $\mathrm{K} 207^{\mathrm{T}}$ & Saccharothrix mutabilis & DSM $43853^{\mathrm{T}}$ & X76966 & RDP \\
\hline
\end{tabular}

${ }^{a}$ NA, not assigned; ${ }^{\mathrm{T}}$, type strain.

${ }^{b}$ Abbreviations: ATCC, American Type Culture Collection, Rockville, Md.; DSM, Deutsche Sammlung von Mikroorganismen und Zellkulturen GmbH, Braunschweig, Germany; IFO, Institute for Fermentation, Higashiyodogawa, Osaka, Japan; INMI, Institute of Microbiology, Moscow, Russia; NCIB, National Collection of Industrial Bacteria, Aberdeen, Scotland; NRRL, Northern Regional Research Laboratory, Agricultural Research Service, U.S. Department of Agriculture, Peoria, Ill. Sources of cultures: V. N. Akimov, Department of Type Cultures, Institute of Microbiology, Moscow, Russia; E. Greiner-Mai, Institut für Mikrobiologie, Technische Hochschule Darmstadt, Darmstadt, Germany; J. Lacey, Plant Pathology Department, Rothamsted Experimental Station, Harpenden, Hertfordshire, United Kingdom; A. J. McCarthy, Department of Genetics and Microbiology, University of Liverpool, Liverpool, United Kingdom; J.-S. Ruan, Institute of Microbiology, Academia Sinica, Zhong Guan Cun, Beijing People's Republic of China; H. Runmao, New Antibiotic Research Department, Sichuan Industrial Institute of Antibiotics, Chengdu, Sichuan, People's Republic of China.

${ }^{c}$ RDP, Ribosomal Database Project release 4 (24)

${ }^{d}$ Isolated on R8 agar (1) at $50^{\circ} \mathrm{C}$.

Madison, Wis.) were used for transformation with the recombinant plasmid pBluescript II SK(+) (Stratagene, La Jolla, Calif.).

DNA extraction. Chromosomal DNA was extracted and purified by a modification of the method of Marmur (26). Wet biomass (ca. $5 \mathrm{~g}$ ) was suspended in $10 \mathrm{ml}$ of TE buffer (10 mM Tris-HCl, 1 mM EDTA; $\mathrm{pH} 8.0$ ) with lysozyme (10 $\mathrm{mg} / \mathrm{ml}$ ) for $15 \mathrm{~min}$ at $37^{\circ} \mathrm{C}$ prior to the addition of $1 \mathrm{ml}$ of $20 \%$ (wt/vol) sodium dodecyl sulfate, $10 \mathrm{ml}$ of TE-saturated phenol, and $1.5 \mathrm{ml}$ of $5 \mathrm{M} \mathrm{NaCl}$. This preparation was centrifuged at $10,000 \times g$ for $10 \mathrm{~min}$, the supernatant was extracted twice with an equal volume of chloroform, and the crude DNA precipitate was recovered with an equal volume of isopropanol. The chromosomal DNA was resuspended in $10 \mathrm{ml}$ of TE buffer and incubated first with RNase A $\left(20 \mu \mathrm{g} / \mathrm{ml}\right.$; Sigma) for $30 \mathrm{~min}$ at $37^{\circ} \mathrm{C}$ and then with proteinase $\mathrm{K}(100 \mu \mathrm{g} / \mathrm{ml}$; Sigma) at $50^{\circ} \mathrm{C}$ for a further $30 \mathrm{~min}$. Following this, the DNA was extracted once again with phenol and twice with chloroform. It was then precipitated with isopropanol, dried, and resuspended in TE buffer.

PCR amplification of 16S rDNA. 16S rDNAs were amplified with two primers, namely, 5'-TCACG GAGAG TTTGA TCCTG-3' (in E. coli numbering, positions 2 to 21 ) and $5^{\prime}$-AGAAA GGAGG TGATC-3' (in E. coli numbering positions 1544 to 1530$)$. The PCR mixtures $(100 \mu \mathrm{l})$ were prepared with $2.5 \mu \mathrm{l}$ of each of the primers $(20 \mu \mathrm{M}), 16 \mu$ l of deoxynucleoside triphosphate mix $(0.5$ $\mathrm{mM}$; dATP, dCTP, dGTP, and dTTP), $1 \mu \mathrm{l}$ of Taq DNA polymerase (5 U:
AmpliTaq; Perkin-Elmer), and $10 \mu \mathrm{l}$ of $10 \times$ AmpliTaq buffer (Perkin-Elmer). Chromosomal DNA (ca. $200 \mathrm{ng}$ ) was added to this solution, which had been made up to $100 \mu \mathrm{l}$ with distilled water. The thermal cycler (Perkin-Elmer model 480 ) used for the thermal amplification was programmed as follows: 35 cycles of

TABLE 2. Numbers of Saccharomonospora colonies isolated on R8 agar plates incubated for 14 days

\begin{tabular}{lcc}
\hline \multicolumn{1}{c}{ Sample } & Temp $\left({ }^{\circ} \mathrm{C}\right)$ & $\mathrm{CFU} \mathrm{g}^{-1}$ \\
\hline Hay & 30 & $3.1 \times 10^{3}$ \\
Mushroom compost & 50 & $2.7 \times 10^{3}$ \\
Phase I & 50 & $8.30 \times 10^{2}$ \\
Phase II & 50 & $5.70 \times 10^{2}$ \\
End of phase II & 50 & $2.30 \times 10^{2}$ \\
Cooked-out phase & 50 & $4.90 \times 10^{2}$ \\
\hline
\end{tabular}




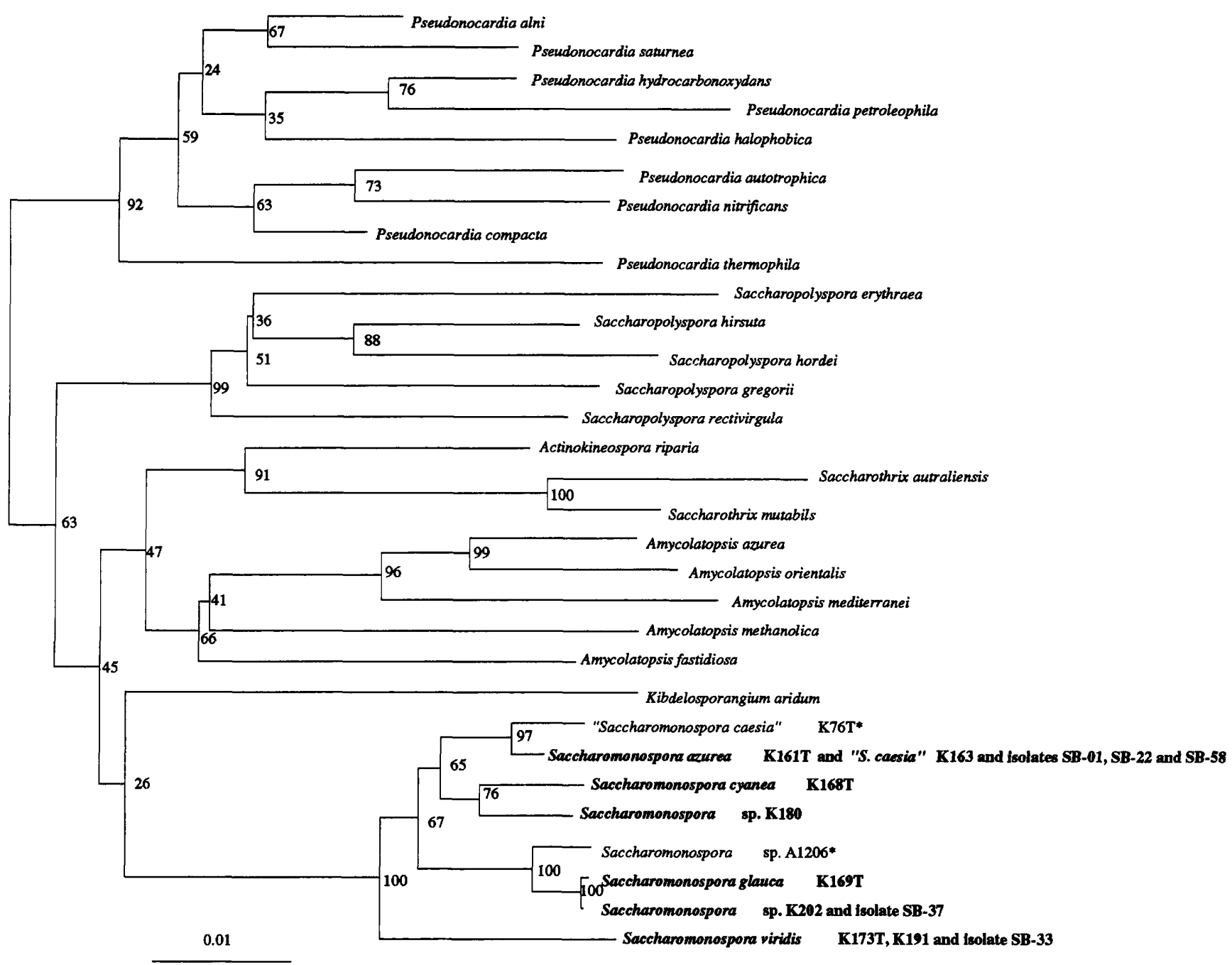

FIG. 1. Phylogenetic tree showing the relationships between different Saccharomonospora species and between them and representatives of genera classified in the family Pseudonocardiaceae. The tree was generated by the neighbor-joining (34) method. The numbers at the nodes indicate the levels of bootstrap (11) support based on data for 1,000 replicates; the scale bar indicates 0.01 substitution per nucleotide position. *, 16S rRNA data from T. M. Embley.

denaturation at $95^{\circ} \mathrm{C}$ for $1 \mathrm{~min}$, primer annealing at $50^{\circ} \mathrm{C}$ for $1 \mathrm{~min}$, and primer extension at $72^{\circ} \mathrm{C}$ for $2 \mathrm{~min}$.

Cloning of amplified 16S rDNA. Amplified 16S rDNA was recovered from 1\% agarose gels in Tris-acetate buffer (0.04 M Tris-acetate, $0.001 \mathrm{M}$ EDTA) and purified by using a Gene Clean II Kit (Bio 101, La Jolla, Calif.). The DNA was dried and dissolved in $10 \mu \mathrm{l}$ of distilled water. Each preparation of PCR fragments $(9 \mu \mathrm{l})$ was mixed with $2 \mu \mathrm{l}$ of pBluescript $\mathrm{T}$ vector digested with $E c o \mathrm{RV}$ $1.5 \mu \mathrm{l}$ of $10 \mathrm{mM}$ ATP, $1 \mu \mathrm{l}$ of T4 DNA ligase, and $1.5 \mu \mathrm{l}$ of $10 \times$ ligase buffer (30
$\mathrm{mM}$ Tris- $\mathrm{HCl}$ [pH 7.8], $100 \mathrm{mM} \mathrm{MgCl}, 100 \mathrm{mM}$ dithiothreitol, and $5 \mathrm{mM}$ ATP) and incubated at $16^{\circ} \mathrm{C}$ for $16 \mathrm{~h}$. White colonies were selected after transformation to DH5 $\alpha \mathrm{F}^{\prime}$

Sequencing of double-stranded $16 S$ rDNA. At least three colonies from the same ligation reaction were selected to confirm the final sequence data and were cultured, and plasmid DNA was isolated. Purified plasmids were sequenced with DNA Sequencing Kits (Biochemical Corp.), according to the manufacturer's protocol, using the primers T3 (5'-ATTAACCCTCACTAAAG-3') and T7 (5'-

TABLE 3. Matrix of similarity values (lower part) and the number of differences (from 1,488 to 1,490 sequences; upper part) of the 16S rDNA sequences of the 13 Saccharomonospora strains

\begin{tabular}{|c|c|c|c|c|c|c|}
\hline Strain identity & $\mathrm{K} 161^{\mathrm{T}}$ & $\mathrm{K} 168^{\mathrm{T}}$ & $\mathrm{K} 169^{\mathrm{T}}$ & $\mathrm{K} 202$ & $\mathrm{~K} 73^{\mathrm{T}}$ & K180 \\
\hline S. azurea $\mathrm{K} 161^{\mathrm{Ta}}$ & & $24 / 1,489$ & $29 / 1,489$ & $28 / 1,489$ & $55 / 1,490$ & $18 / 1,489$ \\
\hline S. cyanea $\mathrm{K} 168^{\mathrm{T}}$ & 98.4 & & $29 / 1,489$ & $28 / 1,489$ & $52 / 1,488$ & $20 / 1,489$ \\
\hline S. glauca $\mathrm{K} 169^{\mathrm{T}}$ & 98.1 & 98.1 & & $1 / 1,490$ & $45 / 1,488$ & $34 / 1,489$ \\
\hline Saccharomonospora sp. strain $\mathrm{K} 202^{b}$ & 98.1 & 98.1 & 99.9 & & $46 / 1,488$ & $33 / 1,489$ \\
\hline$S$. viridis $\mathrm{K} 73^{\mathrm{T} c}$ & 96.3 & 96.5 & 97.0 & 96.9 & & $50 / 1,488$ \\
\hline Saccharomonospora sp. K180 & 98.8 & 98.7 & 97.7 & 97.8 & 96.6 & \\
\hline
\end{tabular}

${ }^{a}$ Identical results were obtained for $S$. azurea $\mathrm{K} 161^{\mathrm{T}}$, "S. caesia" K163, and Saccharomonospora strains SB-01, SB-22, and SB-58.

${ }^{b}$ Identical results were obtained for Saccharomonospora strains K202 and SB-37.

${ }^{c}$ Identical results were obtained for $S$. viridis $\mathrm{K} 73^{\mathrm{T}}$ and K192 and Saccharomonospora strain SB-33. 


S. azurea
S.cyanea
S.glauca
Saccharomonospora sp.
S. viridis
saccharomonospora sp.
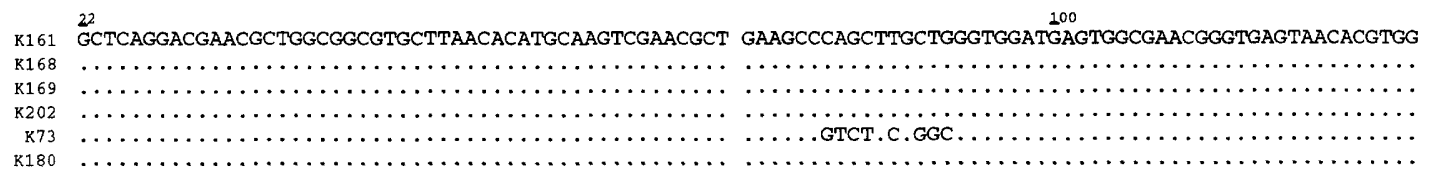

199

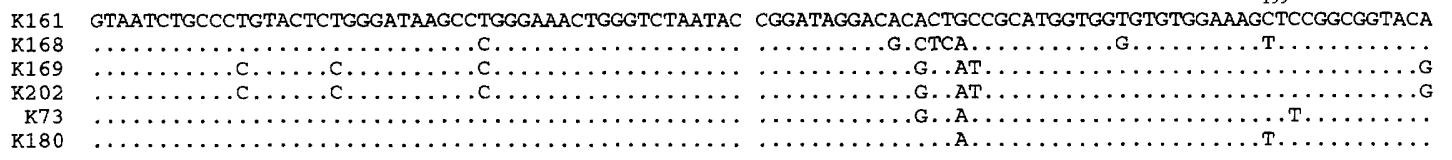

K161 GGTTGAGCCCGCGGCCTATCAGCTTGTTGGTGGGGTGATGGCCTACCAA GGCGACGACGGGTAGCCGGCCTGAGAGGGTGACCGGCCACACTGGGACTGA

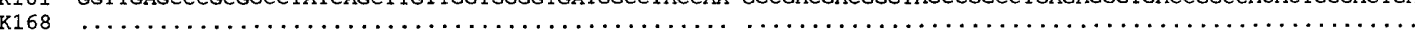

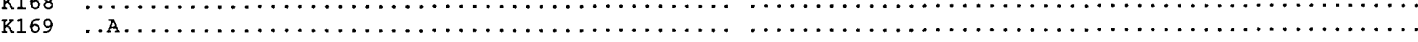

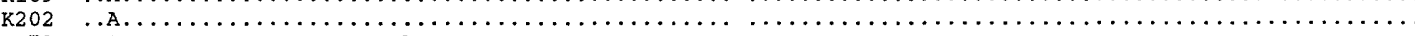

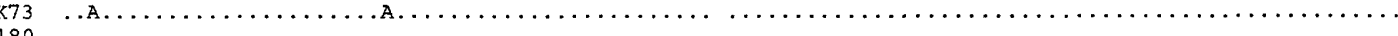

K180

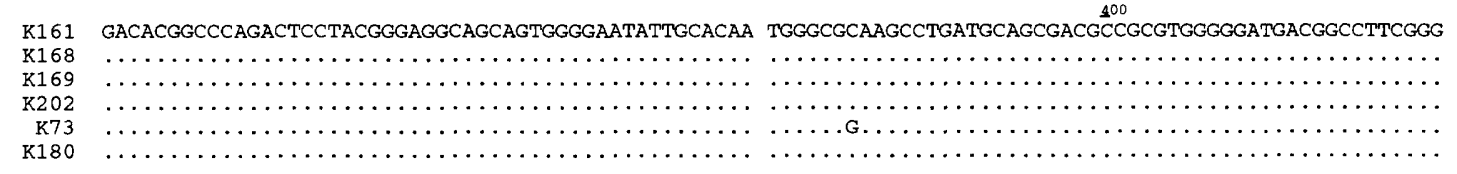

K161 TTGTAAACCCCTTTCGCCAGGGACGAAGCGTAAGTGACGGTACCTGGAG AAGAAGCACCGGCCAACTACGTGCCAGCAGCCGCGGTAATACGTAGGGTGC

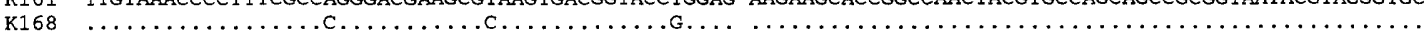

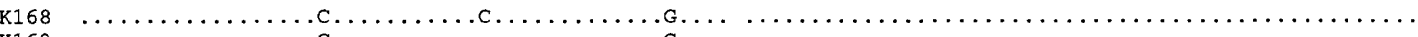

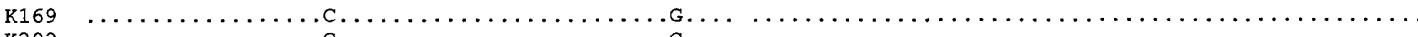

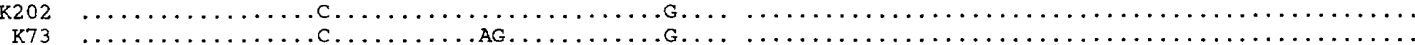

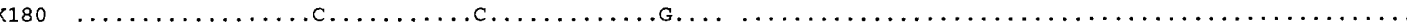

FIG. 2. Aligned $16 \mathrm{~S}$ rDNA sequences including signatures distinguishing between representatives of the genus Saccharomonospora. The numbering system is that of E. coli (6).

AATACGACTCACTATAG-3') of pBluescript II, universal primers (23), and synthesized primers. The samples were electrophoresed in a $6 \%(\mathrm{wt} / \mathrm{vol})$ polyacrylamide-8.3 $\mathrm{M}$ urea gel.

Data analysis. The $16 \mathrm{~S}$ rDNA sequences of the test strains were aligned manually against corresponding sequences of representative Pseudonocardiaceae strains obtained from the Ribosomal Database Project release 4 (24) with the AL16S program (7). Pairwise similarity values were calculated and converted to distances with the algorithm of Jukes and Cantor (19) in the DNADIST program (in PHYLIP, version 3.5c [12]). A phylogenetic tree was generated by the neighbor-joining method (34); Mycobacterium bovis BCG was used as the out-group strain. In order to determine the stability of the resultant phylogenetic tree, the sequence data were resampled 1,000 times for bootstrap analysis (11) using the SEQBOOT program (PHYLIP, version 3.5c).

Nucleotide sequence accession numbers. The $16 \mathrm{~S}$ rDNA sequences determined in this study have been deposited in the EMBL database under the accession numbers listed in Table 1.

\section{RESULTS AND DISCUSSION}

Selective isolation of Saccharomonospora strains. Saccharomonosporae were isolated from the hay and mushroom compost samples only on the R8 agar plates. The target strains were readily recognized, given their capacity to form the green aerial spore mass characteristic of Saccharomonospora strains. The highest number of saccharomonosporae was isolated from the hay sample (Table 2).

16S rDNA sequence analysis. It is evident from the phylogenetic tree (Fig. 1) derived from the nucleotide similarity values (Table 3 ) that the genus Saccharomonospora forms a distinct phyletic line within the evolutionary radiation encompassed by the family Pseudonocardiaceae (36). These data lend weight to the results of earlier studies which showed the genus Saccharomonospora to be a homogeneous taxon on the basis of chemical, morphological, and molecular systematic evidence $(5,10,17,18,31,36)$. The close relationships found between the genus Saccharomonospora and the genera Actinokineospora, Amycolatopsis, Kibdelosporangium, and Saccharothrix need to be interpreted with care, given the low bootstrap values shown in Fig. 1.

The average nucleotide similarity values found between the type strains of the four validly described Saccharomonospora species was $97.5 \% \pm 1.0 \%$. The most distant relationship was found between " $S$. caesia" $\mathrm{K} 163$ and $S$. viridis $\mathrm{K} 73^{\mathrm{T}}(96.3 \%$ similarity). In contrast, $S$. azurea $\mathrm{K} 161^{\mathrm{T}}$ and "S. caesia" K163 had identical 16S rDNA sequences. Additional taxonomic studies are needed to determine the fine relationship between these taxa, as it is well known that sequence identity may not be sufficient to ensure species identity $(13,14)$. This is especially so since $S$. azurea $\mathrm{K} 161^{\mathrm{T}}$ and " $S$. caesia" $\mathrm{K} 76^{\mathrm{T}}$ are also closely related (Fig. 1). It is interesting that all three strains isolated from the mushroom compost were identical in nucleotide sequences both to one another and to the type strain of S. azurea. Similarly, strain SB-33 from hay had a nucleotide sequence identical to that of the type strain of $S$. viridis. The second hay isolate, strain SB-37, had only one nucleotide difference from the sequence shown by the type strain of $S$. glauca.

The present study provides further evidence that the genus Saccharomonospora encompasses undescribed species $(15,27$, 36). The separation of Saccharomonospora sp. strain A1206 from the other test strains (Fig. 1) confirms and extends the earlier work of Warwick et al. (36). Saccharomonospora sp. strain $\mathrm{K} 180$ also forms the nucleus of a distinct center of variation. However, additional comparative taxonomic studies 

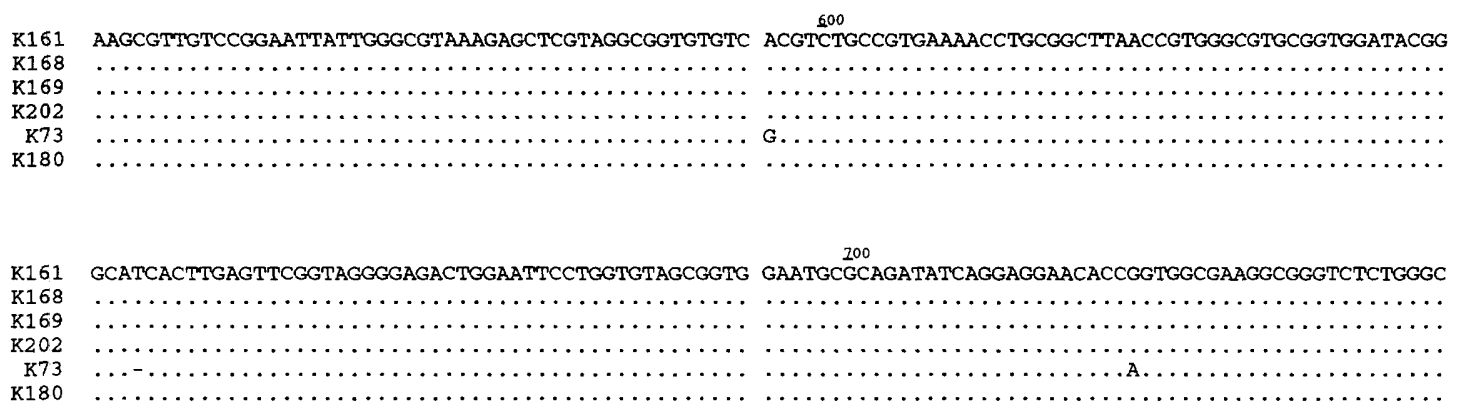

K161 CGATACTGACGCTGAGGAGCGAAAGCGTGGGGAGCGAACAGGATTAGAT ACCCTGGTAGTCCACGCCGTAAACGTTGGGCGCTAGGTGTGGGGCGCTGTT

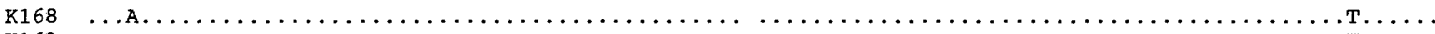

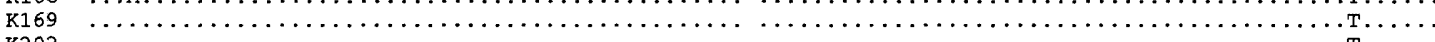

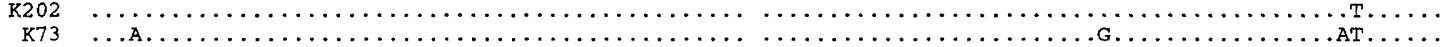

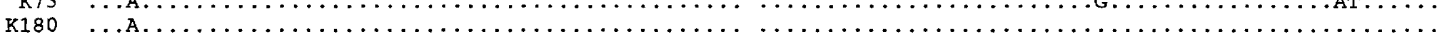

K161 CACGTGTCCCGTGCCGTAGCTAACGCATTAAGCGCCCCGCCTGGGGAGT ACGGCCGCAAGGCTAAAACTCAAAGGAATTGACGGGGGCCCGCACAAGCGG

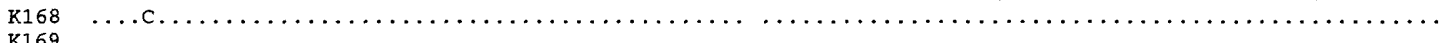

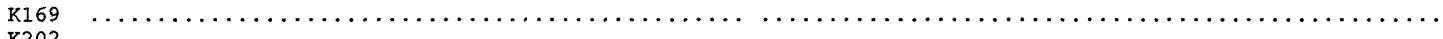

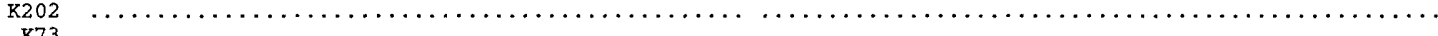

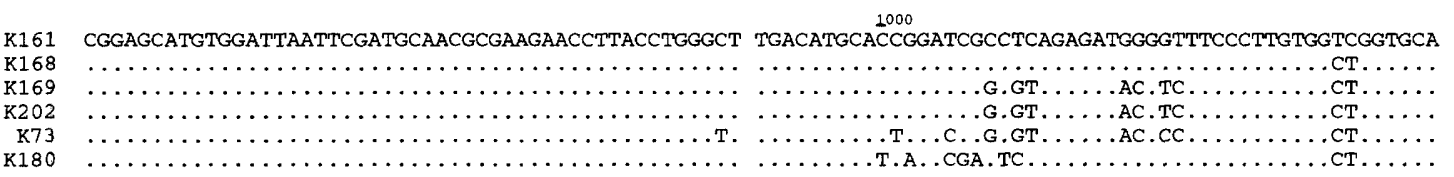

FIG. 2-Continued.

are needed to confirm the taxonomic status of these strains, as it is now generally accepted that the most stable and useful classifications are ones that are based on a combination of genotypic and phenotypic data (29).

The separation of validly described and putatively novel Saccharomonospora species on the basis of 16S rDNA sequence data not only is important in its own right but also opens up the prospect of developing PCR or oligonucleotide probes for identifying unknown saccharomonosporae from environmental samples and clinical material $(4,8)$. 16S rDNA nucleotide signatures that distinguish representatives of the test strains are shown in Fig. 2.

The present investigation provides additional evidence of the value of $16 \mathrm{~S}$ rDNA sequence studies in underpinning the integrity of actinomycete genera and in clarifying relationships within such taxa. This approach together with the application of chemical, morphological, and other molecular systematic techniques can be confidently expected to fuel further advances in actinomycete systematics.

\section{ACKNOWLEDGMENTS}

Sam-Bong Kim is grateful to The British Council (Seoul, Republic of Korea) for financial support and for an Overseas Research Studentship Award. Michael Goodfellow and Yong-Ha Park are grateful for financial support from the Ministry of Science and Technology of the Republic of Korea (grants F-80480 and N-81550).

We are also indebted to the Ribosomal Database Project for access to aligned sequence data and to Jongsik Chun for help with the data analysis.

\section{REFERENCES}

1. Amner, W., C. Edwards, and A. J. McCarthy. 1989. Improved medium for recovery and enumeration of the farmer's lung organism, Saccharomonospora viridis. Appl. Environ. Microbiol. 55:2669-2674.

2. Andersen, A. A. 1958. New sampler for the collection, sizing, and enumeration of viable airborne particles. J. Bacteriol. 76:471-484.

3. Barrowcliff, D. E., and P. G. Arblaster. 1968. Farmer's lung: a study of an early acute fatal case. Thorax 23:490-500.

4. Böddinghaus, B., T. Rogall, T. Flohr, H. Blöcker, and E. C. Böttger. 1990. Detection and identification of mycobacteria by amplication of rRNA. J. Clin. Microbiol. 28:1751-1759.

5. Bowen, T., E. Stackebrandt, M. Dorsch, and T. M. Embley. 1989. The phylogeny of Amycolata autotrophica, Kibdelosporangium aridum and Saccharothrix australiensis. J. Gen. Microbiol. 135:2529-2536.

6. Brosius, J., M. L. Palmer, J. P. Kennedy, and H. F. Noller. 1978. Complete nucleotide sequence of a $16 \mathrm{~S}$ ribosomal RNA gene from Escherichia coli. Proc. Natl. Acad. Sci. USA 75:4801-4808.

7. Chun, J. Unpublished data.

8. DeLong, E. F., G. S. Wickham, and W. R. Pace. 1989. Phylogenetic strains: ribosomal RNA-based probes for the identification of single microbial cells. Science 243:1360-1363.

9. Embley, T. M., J. Smida, and E. Stackebrandt. 1988. Reverse transcriptase sequencing of 16S ribosomal RNA from Faenia rectivirgula, Pseudonocardia thermophila and Saccharopolyspora hirsuta, three wall IV actinomycetes which lack mycolic acids. J. Gen. Microbiol. 134:961-966.

10. Embley, T. M., J. Smida, and E. Stackebrandt. 1988. The phylogeny of mycolateless wall chemotype IV actinomycetes and description of Pseudonocardiaceae fam. nov. Syst. Appl. Microbiol. 11:44-52.

11. Felsenstein, J. 1985. Confidence limits on phylogenies: an approach using the bootstrap. Evolution 39:783-791.

12. Felsenstein, J. 1993. PHYLIP (phylogenetic inference package) version $3.5 \mathrm{c}$. Department of Genetics, University of Washington, Seattle.

13. Fox, G. E., J. D. Wisotzkey, and P. Jurkshuk, Jr. 1992. How close is close: $16 S$ rRNA sequence identity may not be sufficient to guarantee species identity. Int. J. Syst. Bacteriol. 42:166-170.

14. Fry, N. K., S. Warwick, N. A. Saunders, and T. M. Embley. 1991. The use of 16 S ribosomal RNA analyses to investigate the phylogeny of the family 
Legionellaceae. J. Gen. Microbiol. 137:1215-1222.

15. Goodfellow, M., and T. Pirouz. 1982. Numerical classification of sporoactinomycetes containing meso-diaminopimelic acid in the cell wall. J. Gen. Microbiol. 128:503-527.

16. Greene, J. G., M. W. Treuhaft, and R. M. Arnsell. 1981. Hypersensitivity pneumonitis due to Saccharomonospora viridis diagnosed by inhalation challenge. Ann. Allergy 47:449-452.

17. Greiner-Mai, E., F. Korn-Wendisch, and H. J. Kutzner. 1988. Taxonomic revision of the genus Saccharomonospora and description of Saccharomonospora glauca sp. nov. Int. J. Syst. Bacteriol. 38:398-405.

18. Greiner-Mai, E., R. M. Kroppenstedt, F. Korn-Wendisch, and H. J. Kutzner. 1987. Morphological and biochemical characterization and emended descriptions of thermophilic actinomycetes species. Syst. Appl. Microbiol. 9:97-109.

19. Jukes, T. H., and C. R. Cantor. 1969. Evolution of protein molecules, p. 21-132. In H. N. Munro (ed.), Mammalian protein metabolism. Academic Press, Inc., New York.

20. Kalakoutskii, L. V. 1964. A new species of the genus MicropolysporaMicropolyspora caesia n. sp. Microbiology 33:765-768.

21. Kroppenstedt, R. M. 1985. Fatty acid and menaquinone analysis of actinomycetes and related organisms, p. 173-189. In M. Goodfellow and D. E. Minnikin (ed.), Chemical methods in bacterial systematics. Academic Press Ltd., London.

22. Kurup, V. P. 1981. Taxonomic study of some members of Micropolyspora and Saccharomonospora. Microbiologica 4:249-259.

23. Lane, D. J., B. Pace, G. J. Olsen, D. A. Stahl, M. L. Sogin, and N. R. Pace. 1985. Rapid determination of 16S ribosomal RNA sequences for phylogenetic analyses. Proc. Natl. Acad. Sci. USA 82:6955-6959.

24. Larsen, N., G. J. Olsen, B. L. Maidak, M. J. McCaughey, R. Overbeek, T. J. Macke, T. L. Marsh, and C. R. Woese. 1993. The ribosomal database project. Nucleic Acids Res. 21:3021-3023.

25. Lechevalier, M. P., and H. A. Lechevalier. 1970. A critical evaluation of the genera of aerobic actinomycetes, p. 393-405. In H. Prauser (ed.), The Actinomycetales. Gustav Fisher Verlag, Jena, Germany.
26. Marmur, J. 1961. A procedure for the isolation of DNA from microorganisms. J. Mol. Biol. 3:208-218.

27. McCarthy, A. J., and T. Cross. 1984. A taxonomic study of Thermomonospora and other monosporic actinomycetes. J. Gen. Microbiol. 130:5-25.

28. McVeigh, H. P., J. Munro, and T. M. Embley. 1994. The phylogenetic position of Pseudoamycolata halophobica (Akimov et al. 1989) and a proposal to reclassify it as Pseudonocardia halophobica. Int. J. Syst. Bacteriol. 44:300-302.

29. Murray, R. G. F. D. J Brenner, R. R Colwell, P. De Vos, M. Goodfellow, P. A. D. Grimont, N. Pfennig, E. Stackebrandt, and G. A. Zavarzin. 1990. Report of the Ad Hoc Committee on Approaches to Taxonomy within the Proteobacteria. Int. J. Syst. Bacteriol. 40:213-215.

30. Nonomura, H., and Y. Ohara. 1971. Distribution of actinomycetes in soil. X. New genus and species of monosporic actinomycetes. J. Ferment. Technol. 49:895-903.

31. Ochi, K., and M. Yoshida. 1991. Polyacrylamide gel electrophoresis analysis of mycolateless wall chemotype IV actinomycetes. Int. J. Syst. Bacteriol. 41:402-405.

32. Runmao, H. 1987. Saccharomonospora azurea sp. nov., a new species from soil. Int. J. Syst. Bacteriol, 37:60-61.

33. Runmao, H., C. Lin., and W. Guizhen. 1988. Saccharomonospora cyanea sp. nov. Int. J. Syst. Bacteriol. 38:444-446.

34. Saitou, N., and M. Nei. 1987. The neighbor joining method: a new method for constructing phylogenetic trees. Mol. Biol. Evol. 4:406-425.

35. Skerman, V. B. D., V. McGowan, and P. H. A. Sneath. 1980. Approved lists of bacterial names. Int. J. Syst. Bacteriol. 30:225-420.

36. Warwick, S., T. Bowen, H. McVeigh, and T. M. Embley. 1994. A phylogenetic analysis of the family Pseudonocardiaceae and the genera Actinokineospora and Saccharothrix with 16S rRNA sequences and a proposal to combine the genera Amycolata and Pseudonocardia in an emended genus Pseudonocardia. Int. J. Syst. Bacteriol. 44:293-299.

37. Wellington, E. M. H., and S. T. Williams. 1978. Preservation of actinomycete inoculum in frozen glycerol. Microbios Lett. 6:151-159. 